九州大学学術情報リポジトリ

Kyushu University Institutional Repository

\title{
Catastrophic flood in eastern Slovakia
}

Majtan, Stefan

Laboratory of Soil and Water Conservation, Faculty of Agriculture, Kyushu University

Omura, Hiroshi

Laboratory of Soil and Water Conservation, Faculty of Agriculture, Kyushu University

Jelinek, Robert

Geological Institute of Slovak Republic

https://doi.org/10.5109/24322

出版情報：九州大学大学院農学研究院紀要. 44 (1/2)，pp.213-217，1999-11. Kyushu University バージョン：

権利関係 : 
J. Fac. Agr., Kyushu Lniv., $44(1 \cdot 2), 213-217$ (1999)

\title{
Catastrophic flood in eastern Slovakia
}

\author{
Štefan Majtán*, Hiroshi Omura*, Róbert Jelínek** \\ *Laboratory of Soil and Water Conservation, Faculty of Agriculture, Kyushu University \\ **Geological Institute of Slovak Republic, Banská Bystrica, Slovakia. \\ (Receined July 21, 1999 and accepted August 24, 1999)
}

\begin{abstract}
During last year's July, a significant flood struck areas in northwest Eastern Slovakia, 560 kilometers northeast of the capital of Slovakia Bratislava. The affected region is located 30 kilometers northwest of Prešov, the center town of Prešs Districl.

On 20 July 1998 a heavy rain storm struck the villages of Jarovnice, tižovské Pekl'any and Rencišov which are located in the upper part of a $12 \mathrm{~km}$ valley. The heavy rainfall which fell over 90 mimtes caused an unexpected catastrophic flood wave.
\end{abstract}

\section{INTRODUCTION}

In the last years, extensive and heavy rains caused significant flooding in several areas of eastern Slovakia in the Slovak Republic. The most tragic floods have been recorded in July 1997 and also in July 1998.

The most affected areas in Slovak Republic were especially the villages Jarovnice, Užovské Pekl'any and Renčišov in 1998 and Tichý Potok in 1997. In parts of valley where the width is only from 40 to 60 meters, the flood wave reached a height from 4 to 5 meters. There were 55 confirmed deaths. The estimation of general damages has reached 1.2 bilion $\mathrm{Sk}$.

Key words: disaster, flooding, flood wave.

\section{NATURAL SETTING OF DISASTER AREA}

Slovak Republic is located in the Central Europe. Clinlate in Slovakia is continental with hot summers and cold winters. Average annual precipitation in Slovakia Republic is about $800 \mathrm{~mm}$, in disaster area is between $550-650 \mathrm{~mm}$. The annual temperature of disaster area is $7{ }^{\circ} \mathrm{C}$ at south part of Torysa's valley and $4{ }^{\circ} \mathrm{C}$ at peaks of mountain. The coldest month is January with average mirimum temperature $-4^{\circ} \mathrm{C}$. The warmest one is July with average maximum temperature $18^{\circ} \mathrm{C}$ (http SHMU). The highest precipitation month is July and the lowest one is February.

A main river Torysa with its main feeds Sekčov and Delna drains disaster area. The second main river is Svinka on which a catastrophic flow occurred.

\section{Location of disaster}

Renčišov village is a small hamlet located in the uppermost part of valley. One week after the flood the village was accessible only by helicopters and heavy army mashinery. The village has 180 inhabitants. Approximately $90 \%$ of the village roads were destroyed as well as the homes and property of the inhabitants. 
Lžouské Pekl'any village has suffered the greater damage to the property. Twenty percent of the 640 inhabitants are Roma families. The village is located in the narrowwest part of the afflicted valley.

In Jarovnice village, with a population of approximately 4000, the majority of residents are Roma families. The majority of deaths occured in this village and mostly among Roma people.

\section{Meteorological situation}

The center of rainfall was above upstream part of Malá Svinka watershed (Fig. 1). According to meteorologicalist, there was a thunderstorm with two, three cores respectively. The course of flooding was very dramatical. The thunderstorm, with which caused the most catastrophic flood wave, starts from about 3.30 p.m. to 5 p.m., and the first flood occured within an hour since rain started.

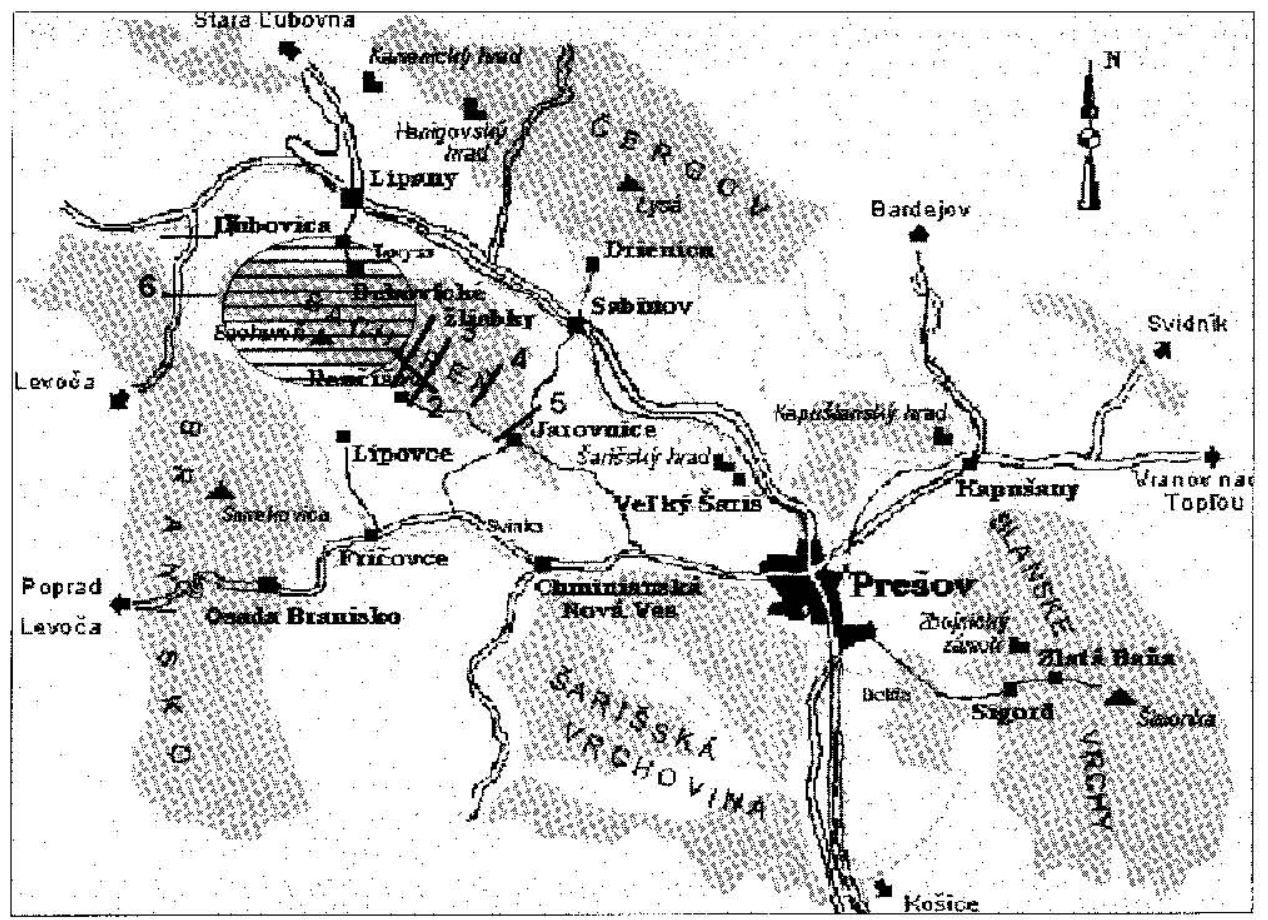

Fig. 1. Schematic map of core rainfall with marked profile selected for calculation of overflow and volume of flood (hitp Region of Prešov). 


\section{RESULT AND DISCUSSION}

\section{Simulation of flood wave}

The most affected village was Užovské Pekl'any. The flood wave started growing up one or one and half hour after rainfall started. The peak of flood wave was reached aproximatelly after two or two and half hour after starting rain. The eligible velocity of flood wave was about $2-2.5 \mathrm{~m} \cdot \mathrm{s}^{-1}$, that means the critical time of flooding in Užovské Pekl'any should had value $80-90$ minutes.

From these conjectures, hydrologists consider, that the overflow in this village was due to whole rainfall and runoff from the whole watershed (Fig. 2). Also, they are considering the culmination overflowing should be reached up to $190 \mathrm{~m}^{3} \mathrm{~s}{ }^{1}$ (Abaffy, Kadubec 1998). In village Dubovica, the same situation should be also, but with lower culnination of overflow about $160 \mathrm{~m}^{2} \mathrm{~s}^{-1}$ (Abaffy, Kadubec 1998).

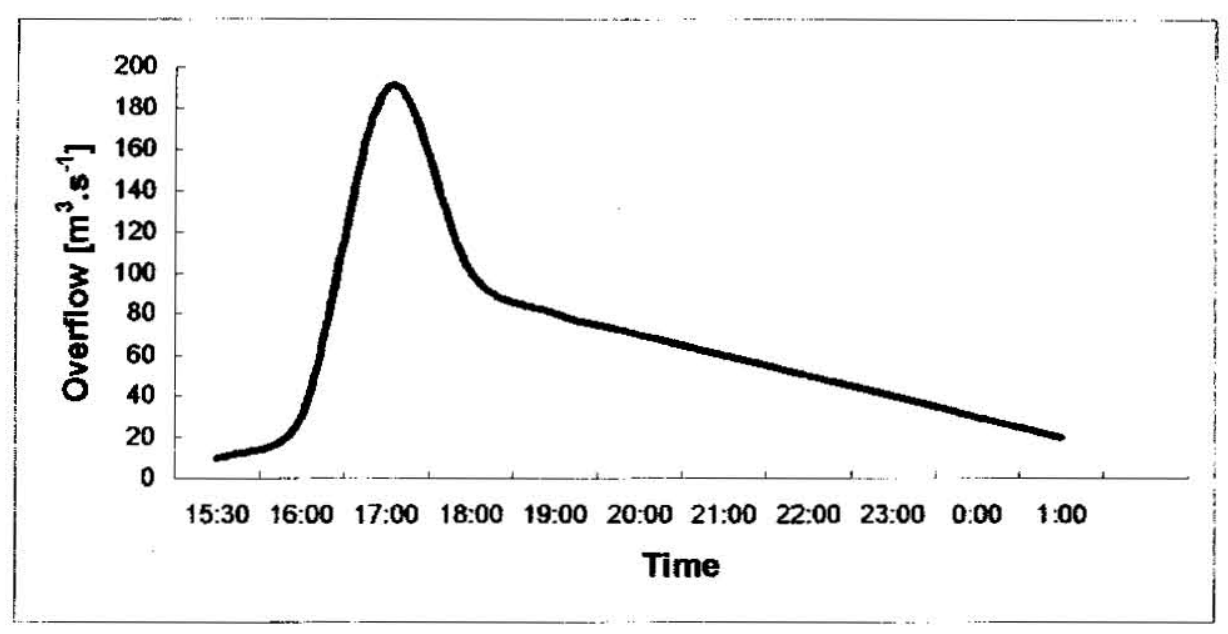

Fig. 2. Calculated course of flooding wave in Užlovské Pekl'any village.

\section{Causes of flooding}

Such catastrophic result of flooding signed especially these factors: rainfall, saturation of watershed by previous rainfall and also lower retentive capacity of area.

Rainfall - as mentioned above, the trigger of flood was heavy rainfall. In the center of thunder cloud it should be reached up to $130 \mathrm{~mm}$. In the short intervals, the intensity of rainfall reached to $3 \mathrm{~mm}$.min-1 and more, which is representative maximum intensity of rainfall in Slovakia.

Saturation of watershed - in 20 July in same area the intensive rainfall occured.

Lower retentive capacity of area - from this point of view the most important factor is hydrogeological structure of area. From an engineering geological point of view, the disaster area is located in the region of the Flysch. Simply, the Flysch complexes are 
composed of heds of sandstones and shales. The complexes with a steep slopes which consist of Flysch formation are incoherent for sliding, break loose following by sliding respectively, after the saturation by water.

Secondary, but also significant catastrophic factors were breach waves. The original places of these waves, were barriers formed by wafting materials (soil, uproot trees and timber, building materials etc.).

\section{Brief account of flooding waves}

The hydrologists from Slovak hydrometric institute reconstructed development of flood waves. Based on this simulation, they are deduced, that in villiges Renčišov, Užovské Pekl'any; Jarovce and Dubovica were in the local stream more than 1000 years recurrence overflows as shown Tab. 1 and Fig. 3 respectively. Their destructive energy was powered by above mentioned breach waves.

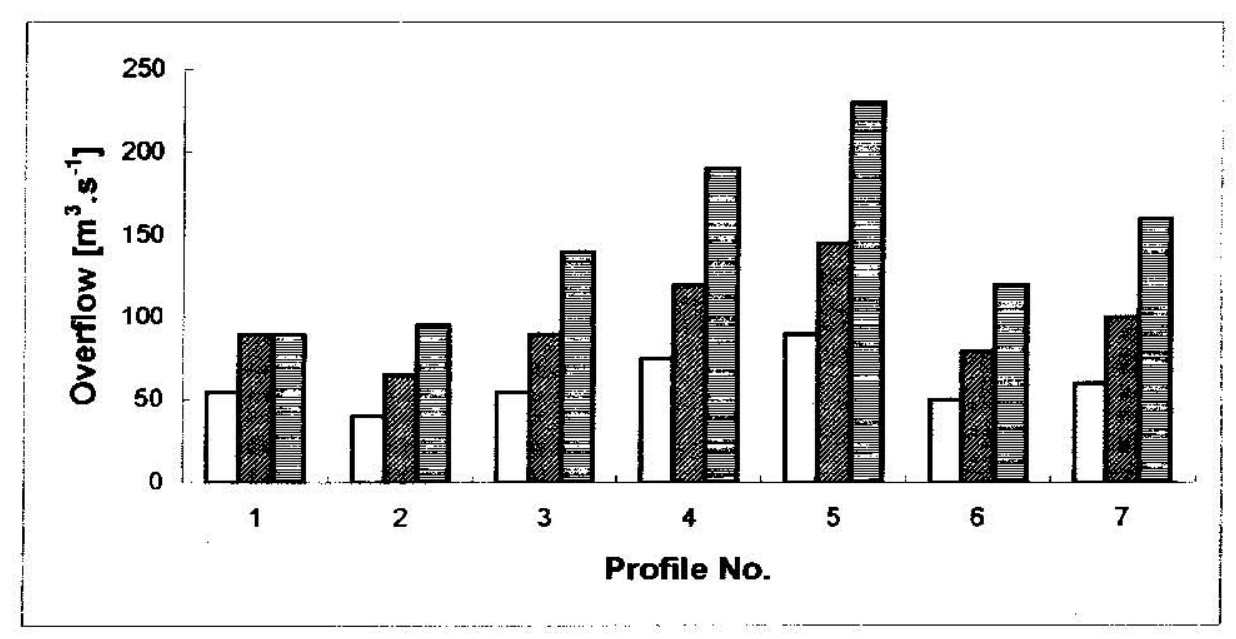

Fig. 3. Shows overflow in selected profiles in order 100 years recurrence, 1000 years recurrence and calculated overflow.

Table 1. Calculated overflow and volume of lood in selected profiles (taken from Majerčáková, Śkoda 1998). The location of profile shows Fig. 1.

\begin{tabular}{|c|c|c|c|c|c|c|c|}
\hline Profile & $\begin{array}{l}\text { Length } \\
\qquad \text { [km] }\end{array}$ & $\begin{array}{l}\text { Area } \\
{\left[\mathrm{km}^{-3}\right]}\end{array}$ & $\begin{array}{l}\text { Forest } \\
\qquad \%\rfloor\end{array}$ & $\begin{array}{l}\text { Slope } \\
\text { watershed } \\
{[\%]}\end{array}$ & $\begin{array}{l}\text { Slope } \\
\text { stream } \\
{[\% 0]}\end{array}$ & $\begin{array}{c}\text { Calculaled } \\
\text { overflou } \\
{\left[\mathrm{m}^{3} \cdot \mathrm{s}^{1}\right]}\end{array}$ & $\begin{array}{l}\text { Calculated volume } \\
\text { of flood } \\
\qquad\left[\mathrm{m}^{3}\right]\end{array}$ \\
\hline 1 & 4.2 & 6.452 & $<50$ & 23 & 8 & 90 & 400000 \\
\hline 2 & 4.3 & 7.065 & $>50$ & 28 & 9 & 95 & 425000 \\
\hline 3 & 6.5 & 13.52 & $>50$ & 25 & 8 & 140 & 825000 \\
\hline 4 & 7.8 & 24.26 & 60 & 26 & 6 & 190 & 1330000 \\
\hline 5 & 13.3 & 35.39 & 50 & 20 & 8 & 230 & 1900000 \\
\hline 6 & 4.45 & 10.9 & 50 & 24 & 9 & 120 & 650000 \\
\hline 7 & 7.35 & 15.244 & 30 & 23 & 6 & 160 & 850000 \\
\hline
\end{tabular}




\section{Facts and numbers about catastrophic flood}

The flooding wave on stream Malá Svinka, Svinka, Žehrica, Torysa and their feeds caused big damages along their course. This water induced disaster killed 55 lifes and 5804 animals. The flood directly affected 10850 people in 82 settlements. Sheiter 756 people were damaged. During the rescue works 3618 people were evacuated. In the befallen area 2059 houses were submerged, 272 houses were destroyed. Also, 13881 ha agriculture land and 4398 ha meadow were flooded. Table 2 . shows brief account of damages caused by flooding in July 1998 at Prešov and Košice district.

Table 2. Main catastrophic affect of flood occured on 20. July in eastern part of Slovakia (taken from Abaffy, Kadubec 1998).

\begin{tabular}{lrrr}
\hline \multirow{2}{*}{ Direct affect of flood } & \multicolumn{2}{c}{ District } & Together \\
\hline City and villages & Prešov & Košice & \\
Overflow houses & 71 & 11 & 82 \\
Ovcrflow sources of drinking water & 1484 & 575 & 2059 \\
Damaged roads [km] & 991 & 476 & 1467 \\
Darnaged bridges and foot - bridges & 87.74 & 22.8 & 110.54 \\
Affected population & 165 & 32 & 197 \\
$\quad$ Thence without shelter & 8379 & 2471 & 10850 \\
Evacuee & 747 & 9 & 756 \\
Death persons & 3608 & 10 & 3618 \\
Injured persons & 55 & 0 & 55 \\
\hline
\end{tabular}

\section{CONCLUSION}

From intensity, extremity, cxtension of damages points of view, the flood in July 1998 was absolutely extraordinaly hydrological phenomena in this century in Slovakia.

Sad to say, that so extraordinaly phenomena have not been registered by an existing net of meteorological station. Concetrated rainfall in certain limited area, like in this cause, indicates that point measurement of rainfall can not record such extreme storm. Therefore, alternative area measurement methods should be used to get the best result.

\section{REFERENCES}

Abaffy, Kadubec 1998 - Fakty a čísla o priebehu a následkoch povodní v Prešovskom a Košickom kraji v júli 1998. Vodohospodárstvo 8/98. pp. 13-17. in Slovak.

http Region of Prešov - Infformation uf Prešov district, Slovakia - http://www.presov.sk.

http SHMU - Web page of Slovak Hydrometeorological Institute in Bratislava, Slovakia http:/www.shmu.sk.

Majerčákuvá, Škoda 1998 - Prívalové povodne na severovýchodnom Slovensku. Vodohospodarstyo 8/98. pp 18-19. in Slovak. 